\title{
A escrita do gênero memórias literárias no espaço escolar: desafios e possibilidades
}

Beth Marcuschi*

* Universidade Federal de

Pernambuco (UFPE)

Este artigo integra o dossiê A produção de textos na Olimpíada de Língua Portuguesa. Em consequência, pressupõe o conhecimento dos pressupostos teóricos e metodológicos da própria Olimpíada, tais como caracterizados na "Introdução" ao dossiê. A análise incidiu sobre 385 produções de alunos do sétimo e do oitavo ano do Ensino Fundamental público; e tomou como objeto de análise as estratégias utilizadas pelos alunos para realizar o gênero em foco nas condições de produção estabelecidas pelo caderno de orientação docente distribuído pela Olimpíada.
RESUMO

O presente estudo assume uma concepção sociodiscursiva de linguagem e desenvolve reflexões sobre os desafios e possibilidades postos ao processo de escrita de memórias literárias na prática pedagógica. Para tanto, explora, inicialmente, as noções de produção escrita, gêneros textuais e processo de didatização. Em seguida discorre mais detalhadamente a respeito do gênero memórias literárias. $\mathrm{Na}$ sequência, analisa, tendo em vista as condições de produção criadas pela Olimpíada de Língua Portuguesa Escrevendo o Futuro, em 2010, um conjunto de textos de memórias literárias produzido por alunos participantes do concurso. Os resultados da investigação apontam para um desempenho satisfatório dos aprendizes no atendimento às condições gerais de produção, ao mesmo tempo em que localizam no manejo do ponto de vista discursivo e no uso da linguagem literária as principais dificuldades enfrentadas pelos alunos.

\section{PALAVRAS-CHAVE}

Memórias literárias. Produção escrita. Espaço escolar. Gêneros textuais. 


\section{INTRODUÇÃO}

No presente artigo, discutimos as características mais salientes de um conjunto de textos do gênero memórias literárias produzido por alunos participantes da Olimpíada de Língua Portuguesa Escrevendo o Futuro, em 2010, procurando identificar os desafios e as perspectivas postos a jovens adolescentes na redação de um gênero textual de pouca incidência e baixa circulação na tradição escolar. Para darmos conta da empreitada, assumimos uma concepção sociodiscursiva de linguagem. Inicialmente debatemos, nesta "Introdução", conceitos básicos para a investigação, tais como as noções de produção textual, gênero textual e processo de didatização. No item subsequente, exploramos aspectos caracterizadores do gênero memórias literárias em seu contexto social de uso no espaço extraescolar. Finalmente, trazemos para o debate as escolhas realizadas pelos alunos na elaboração de seus textos, relacionando-as, sempre que possível, às condições de produção disponibilizadas para os aprendizes nos materiais pedagógicos da Olimpíada, sobretudo no Caderno do professor "Se bem me lembro..." (CENPEC, 2010), especificamente direcionado para a apresentação das oficinas que compõem a sequência didática das memórias literárias.

Uma observação, ainda que breve, das ações por nós realizadas no decorrer da elaboração textual em práticas discursivas diversas, nos permite levantar a hipótese bastante confiável de que o processo de escrita se inicia bem antes de registrarmos no papel e/ou na tela do computador, principalmente, os sentimentos, comentários, ideias, informações, orientações, que desejamos/precisamos compartilhar com outras pessoas, ou ainda queremos reservar para uso ou descarte posterior. A escrita como um processo se faz presente desde o momento em que, em função das práticas sociais e do contexto sócio-histórico nos quais estamos inseridos, constitutivos de nosso repertório linguístico e cultural, executamos um conjunto de atividades, deliberadamente ou não, até chegarmos ao texto que, supomos, atende aos objetivos por nós pretendidos (MILLER, 2009; MARCUSCHI, 2008; BAZERMAN, 2005). Por isso mesmo,

produzir um texto é uma atividade bastante complexa e pressupõe um sujeito não apenas atento às exigências, às necessidades e aos propósitos requeridos por seu contexto sócio-histórico e cultural, mas também capaz de realizar diversas ações e projeções de natureza textual, discursiva e cognitiva, antes e no decorrer da elaboração textual (MARCUSCHI, 2010, p. 65). 
Assim, por exemplo, se queremos preservar nossa imagem diante de uma pessoa hierarquicamente superior, que nos escreve uma mensagem com questionamentos sobre uma tarefa profissional não finalizada, sabemos que convém responder-lhe rápido, com justificativas diretas e plausíveis, numa linguagem polida; se pretendemos vender um objeto, entendemos que o mais interessante é apresentá-lo como atraente para o comprador em potencial; se almejamos dialogar conosco mesmos, registrar o que nos alegra ou incomoda no dia-a-dia, poderemos buscar na escrita de um diário uma alternativa viável; se queremos efetivamente nos cadastrar numa loja, biblioteca, laboratório (virtual ou presencial), compreendemos que é importante preencher adequadamente os dados solicitados na ficha de cadastro etc.

As ações até aqui mencionadas são bastante rotineiras na nossa cultura e, diante de situações análogas, nossos conhecimentos enciclopédicos são convocados para orientar as ações de linguagem nelas relevantes ou desinteressantes, necessárias ou desnecessárias, tendo em vista os propósitos que nos movem, bem antes de começarmos a digitar ou anotar no papel o texto que nos propomos a construir. Essas ponderações sugerem que a escrita dos gêneros textuais não se dá no vácuo, no vazio social, mas ocorre sempre em contextos de práticas. É, nesse sentido, que os gêneros textuais são designados como ações interlocutivas que organizam a vida das pessoas no âmbito das mais diversas práticas sociais (MILLER, 2009; BAZERMAN, 2005). Há, com certeza, práticas que dominamos com mais destreza, por integrarem nossa rotina, enquanto noutras não seremos tão fluentes. Um professor, por exemplo, conhece bem os gêneros textuais que circulam na esfera escolar, mas poderá não ter o mesmo domínio dos gêneros que circulam no âmbito do judiciário.

Justamente por estarem relacionados a domínios discursivos diversos (como o da vida pública, da publicidade, da vida privada, da mídia, da literatura, do judiciário etc.), os gêneros textuais colocam, para o autor, condições de produção diferenciadas, que dele exigem uma compreensão do contexto situacional e um repertório heterogêneo e variado de estratégias discursivas no encaminhamento da elaboração textual. Assim, no processo de escrita, o autor precisa levar em conta, consciente ou inconscientemente, para quem, com que objetivo, sobre o que escreve; o tom (irônico, polido, formal, informal, crítico, conciliador etc.) que deseja imprimir ao seu texto; o suporte (livro, revista, jornal, encarte, sítio etc.) em que o texto irá circular no espaço social; os princípios básicos da textualização (progressão, articulação, coesão, 
coerência etc.), entre outras peculiaridades. Ele também não pode perder de vista que os gêneros textuais não funcionam linearmente e, em graus bastante distintos, tanto impõem regularidades e restrições quanto demandam escolhas e improvisos de natureza linguística e discursiva no contexto das práticas sociais. 0 preenchimento de um formulário coloca restrições mais salientes para o sujeito do que a elaboração de uma publicidade, para ficarmos apenas em exemplos já mencionados. Essa última, inclusive, aceita e até pressupõe um sujeito capaz de transgredir o gênero e de provocar deslizamentos de sentido, o que não é esperado no primeiro caso.

Maingueneau (2009) já diferenciava os gêneros que admitem pouca ou nenhuma variação, na medida em que os sujeitos escritores devem obedecer estritamente às suas coerções, sendo impossível falar de "autoria" para esses gêneros, tais como as cartas comerciais, os formulários burocráticos, os atos notariais etc., dos gêneros tidos como autorais, que não se limitam a seguir um modelo esperado e "cuja cena genérica caracteriza-se por uma incompletude constitutiva” (MAINGUENEAU, 2009, p. 242), tais como, nas palavras do autor, os gêneros ligados ao discurso literário, dentre outros.

As questões até aqui exploradas precisam ser levadas em consideração, quando se trata de propor um encaminhamento pedagógico no ensino da produção de texto com base na abordagem de gêneros textuais. Se, no espaço social, por estarmos imersos em determinadas práticas, conseguimos atender a um conjunto de exigências postas pela escrita, essa proficiência não pode ser esperada na mesma medida de crianças e jovens em processo de formação. Por isso mesmo, na escola, tanto precisamos trabalhar com os gêneros quanto ensiná-los. De acordo com Miller (2009), a aprendizagem de um gênero textual nos possibilita entender melhor as situações em que nos encontramos. Por isso mesmo o ensino da produção textual com base em gêneros pode levar o aluno a compreender como participar de modo ativo das ações de uma comunidade, ou seja, o trabalho pedagógico com os gêneros assume centralidade não pelo fato de os gêneros servirem como um “modelo para aprender a produzir textos bem compostos em sua estrutura formal, mas porque eles permitem [aos alunos e professores] sentirem o próprio fluxo da vida" (MARCUSCHI, 2005, p. 5).

De fato, ao organizarmos o ensino da escrita com base nos gêneros textuais, podemos contribuir para construir junto aos alunos referências 
não apenas em relação aos textos do patrimônio cultural, mas também ao conjunto

da herança social inscrito nas redes da intertextualidade. Damos acesso a "maneiras

de dizer", a configurações de unidades linguísticas que nos foram transmitidas no

decorrer do tempo. Vemos então que o gênero se constitui como o núcleo de uma

aprendizagem integrada de recursos linguageiros; aprender a escrever e a falar

implica a mobilização desses recursos (DOLZ, GAGNON, DECÂNDIO, 2010, p.40).

Um desafio que se apresenta para a prática pedagógica, já discutido por vários autores, entre eles Schneuwly e Dolz, está relacionado ao fato de que, na escola, o gênero textual não é observado como constitutivo das práticas sociais apenas, mas é, ao mesmo tempo, objeto de ensino-aprendizagem. No trabalho pedagógico com as práticas sociais e os gêneros textuais, professores e alunos encontram-se num espaço em que o gênero funciona num outro lugar social, diferente daquele em que foi originado. 0 gênero torna-se "gênero a aprender" (SCHNEUWLY e DOLZ, 2004). Como destacam os autores,

para compreender bem a relação entre os objetos de linguagem trabalhados na escola e os que funcionam como referência é preciso, então, de nosso ponto de vista, partir do fato de que o gênero trabalhado na escola é sempre uma variação do gênero de referência, construída numa dinâmica de ensino-aprendizagem, para funcionar numa instituição cujo objetivo primeiro é precisamente este (SCHNEUWLY e DOLZ, 2004, p. 81).

Para dar conta do desafio de tratar o gênero textual como objeto de ensino sem, contudo, desvirtuar sua prática social de referência, os encaminhamentos pedagógicos precisam ser cuidadosa e adequadamente conduzidos. Embora alguns procedimentos didáticos sejam potencialmente generalizáveis, outros são mais específicos e devem levar em conta as características próprias do gênero e de suas práticas. Com isso, estamos afirmando que não cabe seguir um roteiro fixo de atividades no ensino de gêneros da esfera jornalística e de gêneros da esfera literária, por exemplo.

No nosso estudo, são os textos produzidos pelos alunos, por ocasião da Olimpíada de Língua Portuguesa, edição 2010, na relação com o gênero de referência e as condições de produção oferecidas aos aprendizes, que nos indicarão os ganhos e os obstáculos enfrentados no ensino-aprendizagem das memórias literárias. Na próxima seção exploramos as características e o funcionamento desse gênero nas práticas discursivas extraescolares. Mais adiante nos debruçamos então sobre os textos elaborados pelos alunos. 


\section{O GÊNERO MEMÓRIAS LITERÁRIAS NO CONTEXTO DAS PRÁTICAS SOCIAIS}

Neste item buscamos delinear, do ponto de vista discursivo, as práticas e os fenômenos linguísticos atinentes ao gênero memórias literárias. Para tanto, procuraremos mostrar, de início, que os vários gêneros textuais, em graus variados de abrangência, possibilitam uma visada sobre contextos sóciohistóricos passados, sem contudo se configurarem necessariamente como literários. Por sua vez, há igualmente textos literários que não se ocupam de questões vinculadas às lembranças das pessoas. O gênero memórias literárias se localiza justamente na convergência dessas características. Por isso mesmo, na sequência deste artigo, elegemos observá-lo com base nos dois eixos que, em princípio, o caracterizam no espaço social: a remissão a tempos antigos, desde uma perspectiva contemporânea, e a valorização da singularidade e da estética literária.

O desejo de compreender o universo e seus fenômenos, preservar o passado e manter as tradições da comunidade, via memórias dos mais sábios e experientes, transmitidas oralmente de geração em geração, sempre obcecou as sociedades humanas, desde seus primórdios. Daí a abundância de narrativas, mitos e lendas que floresceram no período. De fato, as sociedades ágrafas dependiam basicamente

\footnotetext{
de sua memória para, ao longo do tempo, reter e transmitir as representações que lhes eram convenientes de perdurar. Para isso, utilizavam recursos como a dramatização, personalização e artificios narrativos diversos, a fim de que as representações tivessem mais chances de sobreviver em um ambiente composto quase unicamente por memórias humanas (LIMA, 2007, p. 276).
}

Com o advento da escrita, as pessoas começaram a fixar na pedra, na madeira, no tecido, no pergaminho, no metal, no papel e em outros suportes as ações, as invenções, as tragédias, as artes, os sentimentos humanos, entre outros acontecimentos, simples ou de maior magnitude. Assim, graças ao empenho de nossos obstinados antepassados, hoje dispomos de registros em razoável quantidade dos saberes e bens culturais construídos ao longo dos séculos pela humanidade, recuperáveis em múltiplos gêneros textuais, como poemas, romances, contos, leis, cartas, regras de jogos, diários, anúncios, reportagens, notícias, resumos, registros de imóveis, anotações escolares, entre tantos outros. Esses registros nos permitem, a partir de um inevitável ponto de vista contemporâneo, analisar, conhecer, estudar, pesquisar e reconstruir as mais diversas práticas sociais. 
Não nos parece exagero afirmar, portanto, que a capacidade latente de acionar práticas discursivas diversas, favorecendo a recuperação e a investigação de contextos sociais mais antigos parece estar subjacente (em menor ou maior extensão) a todo e qualquer gênero textual.

Tomemos como exemplo para respaldar nossas ponderações o anúncio de um possível comerciante da cidade do Recife que, no século XIX, divulgou no Diário de Pernambuco (DP), a venda de "Uma maquina para copiar cartas, e uma burra tudo em bom estado: no Trapiche novo n.176". 0 anúncio do jornal tanto nos permite, hoje, reconstruir alguns dos costumes e necessidades sociais da época, ${ }^{2}$ como nos oferece pistas a respeito da composição textual e da função sociocomunicativa ${ }^{3}$ assumidas pelo gênero anúncio no período (para ficarmos somente em dois aspectos, dentre os muitos que poderiam ser aprofundados). E é justamente a análise das condições de produção que nos possibilita extrair algumas conclusões sobre o anúncio do DP: sua autoria não é identificada; ${ }^{4}$ à época em que foi publicado, ele certamente remetia a uma ação retórica atual (oferecer um produto para venda) e não de tempos idos; alguns dos vocábulos nele utilizados não são mais de uso corrente e, para uma melhor compreensão do anúncio, hoje precisam ser explicados e contextualizados. Esses aspectos (por sua presença ou ausência), dentre outros, serão de significativa relevância na caracterização do gênero memórias

Diário de Pernambuco, Recife, 29 de agosto de 1842. Anúncio reproduzido na coluna “Os pequenos anúncios curiosos do Diário”, do mesmo jornal, em 16 de março de 2011, página $\mathrm{A} 3$.

Os costumes e necessidades do período precisariam ser melhor aprofundados e pesquisados, o que não é nosso objetivo aqui; mas é possível supor que "cartas" eram escritas e distribuídas em quantidade razoável por certas instâncias (comércio, escritórios, judiciário, por exemplo), daí a ajuda que uma máquina poderia oferecer. Também é possível inferir que objetos valiosos eram cuidadosamente armazenados, por isso a expectativa de que uma "burra" ("caixa ger. de madeira em que se guardavam e/ou transportavam coisas diversas, esp. valores", dinheiro etc.; cofre, dentre outros significados, segundo o Houaiss, Grande Dicionário da Língua Portuguesa) encontrasse compradores.

Sabe-se que os jornais, à época, tinham circulação restrita, mas também que o DP gozava de grande prestígio local. Portanto, pode-se inferir que o anúncio se dirigia a pessoas com razoável proficiência em leitura, conhecimento da linguagem quase cifrada da publicidade, algum poder aquisitivo etc.; percebe-se ainda, pela expressão "tudo em bom estado", que o anúncio cuidava de destacar as qualidades que poderiam valorizar os produtos.

O que "personaliza” o anúncio é a indicação de um endereço, mais precisamente, do "Trapiche" (espécie de pier pequeno e de madeira associado a um armazém para embarque, desembarque e comercialização de mercadorias) em que os produtos se encontravam à venda. 
literárias, como veremos adiante. Consideremos, na continuidade de nossas reflexões, um trecho extraído de um artigo acadêmico, de autoria declarada:

Até os séculos II-III d.C., "ler um livro" significava normalmente ler um rolo: pegava-

se o rolo com a mão direita, desenrolando-o progressivamente com a esquerda, a qual segurava a parte já lida; acabada a leitura, o rolo permanecia enrolado na mão esquerda. Essas diversas fases, bem como certos gestos e atitudes complementares, são largamente demonstrados nas representações iconográficas, sobretudo nos monumentos funerários. Neles encontramos o rolo que é seguro com a mão direita, enquanto a esquerda começa a desenrolá-lo, fase inicial da leitura; (...) o rolo aberto no tipo chamado da

"leitura interrompida", seguro com apenas uma mão que, reunindo os dois cilindros nas extremidades, deixa livre a outra mão; (...) o rolo, enfim, novamente enrolado, seguro pela mão esquerda (CAVALLO, 1998, p. 78).

No trecho em questão, Guglielmo Cavallo, conhecido paleontólogo e historiador italiano, descreve, em função de pesquisas por ele realizadas, o que significava "ler um livro" nos primeiros séculos depois de Cristo. 0 autor, tido como referência em sua área, escreve em princípio para seus pares, e fala sobre "certos gestos e atitudes complementares" à leitura de sujeitos que viveram há séculos em Roma. Esses atos, apesar de localizados num passado bem distante, são apresentados como plenamente exequíveis (condição tida como relevante numa pesquisa científica), pois, no entender de Cavallo, são “largamente demonstrados nas representações iconográficas”. O vocabulário do artigo é atual e de fácil compreensão, apesar do uso de alguns poucos termos técnicos mais sofisticados e específicos da área.

As condições de produção do artigo acadêmico e do anúncio, aqui apenas brevemente alinhavadas, são bastante distintas. Por ser de interesse para o nosso estudo é importante, no entanto, trazer à tona duas características comuns aos dois gêneros textuais: ambos permitem recuperar, por caminhos discursivos totalmente distintos, acontecimentos constitutivos de nossa memória cultural, seja local ou universal; e ambos "não" evidenciam explicitamente uma preocupação de natureza estética, nem lidam com o ficcional, o que os distancia de gêneros da esfera literária. Considerando a segunda característica, direcionemos então nossa atenção para o contexto discursivo da literatura.

Gêneros como conto, romance, poema etc. são rotineiramente vinculados à esfera literária, enquanto gêneros como anúncio, receita culinária, reportagem, artigo científico etc. não o são. Apesar dessa constatação ser aparentemente simples e óbvia, não há consenso, nem entre os teóricos da literatura, os críticos literários, os aficionados pela literatura, e nem entre os usuários de modo geral, sobre quais fenômenos essencialmente determinam as fronteiras 
da literariedade de um texto. Estabelecer esses limites não é tarefa simples, nem talvez possível, pois "o ponto de equilíbrio entre o que une e o que separa práticas culturais nunca foi fácil de encontrar” (PAULINO, 2005, p. 57). A noção de literariedade constitui, não há dúvida, um conceito complexo, polissêmico, histórica e culturalmente situado e, ao debatê-lo, não é nossa pretensão esgotá-lo, nem estabelecer uma dicotomia entre o literário e o não-literário; simplesmente nos propomos a situar a perspectiva aqui assumida.

Maingueneau (2009) nos ajuda a refletir sobre a noção de literatura, na medida em que ele toma o texto literário como um discurso, no qual texto e contexto estão absolutamente imbricados, ou, dito de outra forma, no qual o texto é a própria configuração do contexto. Isto significa, em outras palavras, que para Maingueneau o contexto não é exterior à obra, e que o discurso literário e as práticas sociais estão incontornavelmente inter-relacionados, pois

\footnotetext{
não há, de um lado, um universo de coisas e atividades mudas e, do outro,

representações literárias dele apartadas que sejam uma imagem sua. Também a

literatura constitui uma atividade; ela não apenas mantém um discurso sobre o mundo, como produz sua própria presença nesse mundo (MAINGUENEAU, 2009, p. 44).
}

Considerar o fato literário como um discurso é, na perspectiva do autor, distanciar-se do "universo estético aberto pelo romantismo em que o centro, direta ou indiretamente, era a individualidade criadora" (MAINGUENEAU, 2009, p. 43), a inspiração subjetiva do escritor, à revelia de sua função social. Considerar o fato literário como um discurso é relacionar o autor e sua obra com a contingência histórica que lhe deu vida, é considerar "seus ritos de escrita, seus suportes materiais, sua cena de enunciação" (MAINGUENEAU, 2009, p. 44).

Com Maingueneau, assumimos então que a subjetividade criadora não pode ser vista independentemente de sua atividade de escrita, de suas condições de produção e de uso. Assim, “o texto literário, além de acumular esteticamente muitos outros textos, revela e questiona também convenções, norma e valores sociais" (PAULINO, 2005, p. 60), pressupondo, nos papéis de autor e de leitor, sujeitos que se posicionam sobre o mundo.

Complementarmente, entendemos que o gênero literário "tem como uma de suas características principais a ficcionalidade" (JAGUARIBE, 2007, p. 221222), ou seja, embora se assente no real, seu discurso sobre o mundo pode subverter a lógica tida como natural. Mais explicitamente, os gêneros da literatura se distinguem (embora essa distinção nem sempre seja simples de ser identificada) dos gêneros de outras formações discursivas por certa 
transgressão do real, por um olhar próprio e reflexivo dos acontecimentos históricos e sociais, pelo uso mais intenso de recursos estilísticos da linguagem, pela aspiração de provocar experiências estéticas, éticas, ideológicas etc. no leitor presumido. Como destaca Paulino, nos gêneros da esfera literária,

os automatismos de percepção textual do leitor passariam para um segundo plano, embora, por outro lado, os protocolos culturais estabeleçam limites e regras para as suas ações, como estabelecem para as textualizações. Institui-se assim um jogo entre tais protocolos e o caráter difuso, alógico, do imaginário, configurado e mobilizado pela ficção. Cria-se, ao mesmo tempo, uma ponte e um abismo entre um real social representado ficcionalmente - representação esta que, entre outras dimensões sociais, impõe uma necessidade de interpretação coerente pelo leitor - $e$ a dimensão imaginária envolvida na leitura (PAULINO, 2005, p. 60).

Há, certamente, um conjunto expressivo de gêneros da esfera literária que atendem aos parâmetros elencados e precisamos ir em busca de outros critérios, se quisermos distingui-los entre si, se quisermos mais precisamente caracterizar as memórias literárias. Observemos, por exemplo, que no âmbito social há uma expectativa de que certas temáticas e/ou peculiaridades discursivas estejam mais relacionadas a determinados gêneros literários do que a outros. Assim, por sua tipificação sócio-histórica no âmbito das práticas sociais, os relatos de experiências simples do cotidiano são comumente relacionados a crônicas literárias; os relatos sobre a vida pessoal, do diaa-dia, a diários; as narrativas envolvendo um ensinamento moral e animais com propriedades antropomórficas a fábulas; as narrativas que exploram a relação do homem com o mundo e procuram explicar, de maneira mágica, os fenômenos da natureza, o surgimento do mundo e do universo, a mitos etc. Como se percebe, os gêneros citados não são associados à recuperação, no presente, de lembranças antigas atravessadas pelo imaginário do autor e, por essa razão, não atendem a uma das especificidades mais esperadas nas memórias literárias.

As memórias literárias têm como propósito sociocomunicativo mais saliente recuperar, numa narrativa escrita de uma perspectiva contemporânea, vivências de tempos mais remotos (relacionadas a lugares, objetos, pessoas, fatos, sentimentos, valores etc.) experienciadas pelo autor (ou que the tenham sido contadas por outrem, mas que lhe digam respeito), numa linguagem que se configure como um ato discursivo próprio e recrie o real, sem um compromisso com a veracidade ou com a magnitude das ocorrências. De fato, o distanciamento temporal e as mudanças de valores, experiências e desejos e ele associadas inevitavelmente levam o memorialista a reconfigurar as 
passagens que as lembranças trazem à tona. Recordar é, assim, adicionar ao passado detalhes e cores que (provavelmente) não estavam lá, mas que foram sendo elaborados e reconfigurados ao longo dos tempos. Como bem aponta Saramago, na obra em que resgata histórias de seus primeiros quinze anos de vida,

\footnotetext{
a criança que eu fui não viu a paisagem tal como o adulto em que se tornou seria tentado a imaginá-la desde a sua altura de homem. A criança, durante o tempo que o foi, estava simplesmente na paisagem, fazia parte dela, não dizia nem pensava, por estas ou outras palavras: "Que bela paisagem, que magnífico panorama, que deslumbrante ponto de vista!" (...) Já não existe a casa em que nasci (...). Essa perda, porém, há muito tempo que deixou de me causar sofrimento porque, pelo poder reconstrutor da memória, posso levantar em cada instante as suas paredes brancas, plantar a oliveira que dava sombra à entrada, abrir e fechar o postigo da porta e a cancela do quintal (...). (SARAMAGO, 2006, p. 13/16, ênfases do autor).
}

Nas práticas sociais, a noção de memórias literárias tem delimitações difusas e opacas e tanto pode ser caracterizada como um gênero em si, materializado em determinados textos (como na obra “Anarquistas, graças a Deus - Memórias”, de Zélia Gattai), quanto ser entendido como um discurso que atravessa gêneros de maior fôlego (como no romance “O filho eterno", de Cristóvão Tezza), ou de menor extensão (como no poema "Confidência do Itabirano", de Carlos Drummond de Andrade). Em qualquer dos casos, o autor retoma lembranças por ele vivenciadas ou a ele relatadas, opera com múltiplas vozes, ao narrar as ocorrências em primeira pessoa, preferencialmente, ou, por delegação do narrador, em terceira pessoa, e assume graus de ficcionalidade diversos. Não há, nas memórias literárias, um compromisso com a fidelidade histórica, nem com os acontecimentos mais grandiosos ou proeminentes, mas com as vivências que afetam a memória afetiva, a memória involuntária e a memória dos sentidos. É importante, por isso mesmo, distinguir o gênero memórias literárias da autobiografia, que retrata preferencialmente momentos e aspectos de uma vida que, por diferentes razões, se tornou célebre, via depoimentos pessoais, e que "através de algumas pistas textuais - como nomes completos de familiares, localizações temporais e espaciais mais específicas - propõe ao leitor um pacto autobiográfico" (CORRÊA, 2007, p.166).

O tempo e a experiência de vida parecem ser os grandes aliados do memorialista, pois é preciso primeiro viver para depois narrar. Talvez por isso o memorialista se configure, via de regra, como uma pessoa madura, de olhar atento, capaz de, na relação com as práticas culturais, elaborar os acontecimentos de sua história de vida, capaz de reconstruir acontecimentos arquivados na memória, sem se importar e até lidando com o fato de que, a qualquer momento, a 
memória pode traí-lo, levando-o a inventar e lapidar cenas e cenários.

É bastante significativa a passagem em que Pedro Nava, um dos mais reconhecidos memorialistas brasileiros, revela em seu romance "Balão Cativo" muito do seu processo de maturação. 0 autor se define como um

menino, moreno, tímido, meio sonso que se esgueirava entre os grandes e gostava de ficar pelos cantos olhando tudo, ouvindo tudo, guardando tudo, tudo. Armazenando na memória (meu futuro martírio) os fragmentos de um presente jamais apanhável, mas que ele sedimentava e ia socando quando eles caíam mortos e virados no passado de cada instante (NAVA, 1977, p. 228).

Em seu estudo sobre Pedro Nava, Aguiar (1998, p. 17) nos revela a postura de arquivista do escritor, que guardava "documentos de família, fotografias, cartas, diários, bilhetes, frases soltas, citações de livros etc.”. Aguiar (1998) também nos ajuda a compreender a importância da etapa de "garimpagem" dos acontecimentos passados no processo de escrita de Nava, pois nem tudo que está no "baú das memórias" será retomado, e nem tudo que será retomado tem um compromisso com o real:

Para Nava, rememorar é dar vida aos desaparecidos no tempo, assim como escrever sobre eles é convertê-los em matéria literária. As figuras mortas deixam a sua condição "de realidade" e saltam para a configuração de personagens. De algum modo, rememorar está para o documento - aqui no sentido de "pura lembrança" - assim como dar vida nova aos mortos está para a ficção, no sentido de lembrança transfigurada pela criação artística. Combinados, os dois processos explicam a arte do escritor das Memórias (...). Como não poderia deixar de ser, a fonte principal do trabalho literário de Nava é ele mesmo, ou seja, sua capacidade de operacionalizar criativamente a própria memória. Contudo, esta somente, sem apoio da documentação e do método, não o teria levado tão longe (AGUIAR, 1998, p. 17-18).

E poderíamos acrescentar, respaldados em Maingueneau, que a subjetividade criadora de Nava está estreitamente relacionada a condições de produção de diversas naturezas, tais como: o contexto sócio-histórico no qual ele se achava inserido; as práticas sociais familiares; a convivência intensa com 0 Modernismo e com escritores marcantes da literatura brasileira; o espaço que ele passou a ocupar no contexto literário nacional após a eclosão tardia, aos 65 anos, de sua obra.

No âmbito das práticas pedagógicas, tais como as propostas pela Olimpíada Escrevendo o Futuro, o gênero memórias literárias adquire contornos mais definidos e transparentes dos que os até aqui debatidos, além de assumir um novo e decisivo traço: as memórias não são propriamente do autor (aluno), mas de uma terceira pessoa, cuja perspectiva, todavia, precisa ser assumida 
pelo narrador/autor (aluno) em primeira pessoa. Desse modo cabe ao aprendiz, com base numa temática previamente delimitada, ir em busca de memórias de pessoas mais velhas da comunidade, que se configurem como interessantes para os propósitos previstos pela Olimpíada, para em seguida relatá-las, como já enfatizado, como se fossem suas próprias memórias, ou seja, em primeira pessoa. Trata-se de um processo bastante complexo para jovens escritores ainda em formação e que, por isso mesmo, precisa ser devidamente dimensionado e encaminhado no decorrer das atividades de didatização. Consideremos, pois, no próximo item, como os alunos cuidaram dessa e de outras questões relacionadas à produção das memórias literárias.

\section{OS TEXTOS DE MEMÓRIAS LITERÁRIAS ELABORADOS PELOS ALUNOS}

Para a construção da análise que se segue, foram lidos 385 textos do gênero memórias literárias elaborados por alunos de sétimo e oitavo anos do Ensino Fundamental participantes da Olimpíada da Língua Portuguesa Escrevendo o Futuro, edição 2010. A amostra, organizada pelo Centro de Estudos em Pesquisas em Educação, Cultura e Ação Comunitária - Cenpec, representa equitativamente os diferentes municípios, regiões e escolas do País envolvidos nas atividades da Olimpíada daquele ano.

Ao longo de uma sequência didática, organizada em 16 oficinas e ministradas pelos professores no primeiro semestre de 2010,5 os alunos foram preparados para a realização de uma tarefa bastante específica: redigir um texto do gênero memórias literárias que trouxesse à tona as vivências de moradores da comunidade (em primeira pessoa e em linguagem literária); que atendesse ao tema "o lugar onde vivo"; ${ }^{6}$ que levasse em conta os leitores das várias etapas da Olimpíada; que considerasse critérios de textualidade (coesão, progressão e coerência próprias à lógica interna da narrativa) e as convenções da escrita. Vê-se que as condições de produção disponibilizadas no espaço escolar para o aluno, a começar pelas motivações para a escrita (participar de um concurso), delimitação do gênero a ser elaborado (no nosso caso, memórias literárias) e do tema a ser desenvolvido (O lugar onde vivo), são distintas daquelas que se apresentam para o autor nas práticas sociais

As oficinas foram efetivadas com base em materiais pedagógicos sobre o gênero memórias literárias elaborados e disponibilizados pelo Cenpec, a saber: "Caderno do Professor" (com orientações para o ensino da escrita do gênero em pauta), "Coletânea: memórias literárias" (com os textos trabalhados nas oficinas) e CD-ROM (com textos da coletânea e outros complementares em duas modalidades: áudio ou para impressão/ apresentação em datashow).

O tema é estabelecido pelo concurso e deve ser desenvolvido por todos os participantes, independentemente do gênero textual envolvido na escrita.

cadernoscenpec | São Paulo | v.2 | n.1 | p.47-73 | julho 2012 
extraescolares. Essa divergência é um dos desafios que se apresenta à didatização dos gêneros textuais, pois a escola, como vimos na 'Introdução', precisa operar com uma espécie de modelo do gênero de referência a ser ensinado, enquanto nas práticas sociais esse mesmo gênero está sujeito a variabilidades de natureza sócio-histórica, cultural e até mesmo estrutural.

A Olimpíada, juntamente à formação continuada do professor, busca dar conta, com base numa metodologia específica, de parte dos conteúdos de Língua Portuguesa que, de acordo com os currículos, precisam ser ensinados. De fato, na apresentação do caderno "Se bem me lembro..." indica-se claramente que a

Olimpíada não está em busca de talentos, mas tem o firme propósito de contribuir para a melhoria da escrita de todos. O importante é que os alunos cheguem ao final da sequência didática tendo aprendido a se comunicar com competência no gênero estudado. Isso contribuirá para que se tornem cidadãos mais bem preparados

Tendo em vista as condições de produção estipuladas pelos materiais da Olimpíada, os comentários sobre os textos dos aprendizes estão organizados em torno de três focos principais: atendimento ao gênero textual, ao tema, e à organização textual e linguística. Não há, ao longo da análise, uma preocupação com informações estatísticas, mas sim com dados indiciários que contribuam para reflexões a respeito da construção da proficiência dos alunos no gênero focalizado.

\subsection{O GÊNERO MEMÓRIAS LITERÁRIAS E OS TEXTOS DOS ALUNOS}

Como frisamos anteriormente, para dar conta do gênero memórias literárias no contexto da Olimpíada o aluno deveria: 1) recuperar lembranças sobre o passado cultural da localidade pela perspectiva de um antigo morador; 2) apresentar as reminiscências por ele recolhidas como se fossem suas, ou seja, escrever uma narrativa em primeira pessoa; 3) cuidar para que o texto entremeasse acontecimentos reais e ficcionais, com uma linguagem própria e pertinente à esfera da literatura, buscando envolver o leitor. Na amostra analisada, poucos textos atendem aos três critérios elencados. Em grande parte, os textos reconstroem lembranças de tempos antigos, mas na forma de constatações e depoimentos objetivos. Por sua vez, o ponto de vista narrativo oscila entre a primeira e a terceira pessoa, enquanto o entrelaçamento realidade/ficção e o uso da linguagem literária são bastante restritos. Vejamos alguns exemplos:

A estrutura e a organização formal dos textos foram mantidas tal como no original. Por uma questão de espaço, os textos não são reproduzidos na íntegra. Os cortes estão 
Custo a acreditar que tudo aquilo que por nós, a molecada de minha infância, era tido como um paraíso, hoje já não o seja mais. É a influência do progresso... Tenho saudades daqueles tempos em que simplicidade das coisas e o valor a natureza, mesmo frente às dificuldades da vida, prevaleciam sempre. $O$ meu paraíso se encontrava em uma pacata localidade do interior do Paraná, [nome do município], ${ }^{8}$ cidade que carrega em si traços bastante visíveis da colonização dos imigrantes poloneses, alemães e ucranianos. Me lembro bem de cada trilha que era percorrida por mim e por meus amigos A. e M. ... Em cada folha de árvore, misturado ao cheiro da mata, predominava o cheiro do poeirão. Toda vez era assim, e cada uma delas parecia única, no meio da trilha sentíamos um "click" que nos chamava para o mesmo lugar: a belíssima cachoeira [...], rio que ficava próximo de minha casa. Lá brincávamos até o sol nos abandonar. (...) Comparado, aos tempos de minha infância, [nome do município] mudou muito. Hoje vivo com minha esposa e filhos procurando passar a eles um pouco dos ensinamentos que tive e do valor representado pelas coisas mais simples da vida (...). Memórias do Sr. B. K por V.K., aluna-autora.

O aluno/autor do texto reproduzido no exemplo 1 elaborou com êxito uma narrativa em primeira pessoa. As lembranças resgatadas se reportam a vivências pessoais e à "pacata localidade". Para caracterizá-la o narrador salienta, por exemplo, a beleza da cascata, a proximidade do rio, o cheiro da mata e os "traços bastante visíveis da colonização dos imigrantes poloneses, alemães e ucranianos”. São detalhes esparsos, que apelam aos sentidos (olfato, visão, audição) e que, mesmo sendo parcimoniosamente desdobrados, permitem ao leitor acompanhar as reminiscências do autor e elaborar uma imagem sobre a topografia, o cotidiano e as brincadeiras do lugar. A linguagem literária se faz presente, ainda que de forma episódica, no uso de metáforas e outras figuras de linguagem, como nos trechos: "o meu paraíso"; "toda vez era assim, e cada uma delas parecia única”; "sentíamos um 'click' que nos chamava”; “lá brincávamos até o sol nos abandonar”.

As evidências de uma narrativa ficcional que, em alguns momentos, perpassam as memórias do exemplo 1, sofrem, no entanto, uma quebra de continuidade ao término do texto. Há uma espécie de retorno a uma realidade objetiva ("comparado, aos tempos de minha infância, [nome do município] mudou muito. Hoje vivo com minha esposa e filhos procurando passar a eles..."), o que causa prejuízos ao envolvimento do leitor com o gênero. Por sua vez, na indicação final de que as recordações são de “B. K.”, enquanto a elaboração textual é de “V. K.", a didatização do trabalho com as memórias fica bastante

devidamente indicados por sinais gráficos.

Para preservar a identidade dos estudantes, seus nomes, das pessoas entrevistadas por eles e das cidades e bairros a que se referem foram retirados. 
saliente. Como não se espera que alunos adolescentes já tenham acumulado vivências próprias, passíveis de serem retomadas na forma de memórias, a recomendação pedagógica de levar os alunos a buscar contato com pessoas mais experientes da comunidade e de resgatarem suas reminiscências é, certamente, produtiva. No entanto, a objetivação dessas informações, sem a desejável integração das múltiplas vozes no discurso, acaba por distanciar o texto escolar do gênero de referência memórias literárias. Para o aprendiz essa é certamente uma condição de complexa operacionalização no encaminhamento da produção textual.

\section{EXEMPLO 2}

$O$ texto a seguir relata praticamente quase toda história de B. C. Ele gostou de relembrar junto a mim os acontecimentos e histórias do passado. “Quando era pequeno, aí pelos 5 anos, éramos pobres. As famílias eram grandes com aproximadamente 9 irmãos. Lembro que sempre íamos a igreja sem calçados, pois não tínhamos condições de comprá-los. (...). Com 7 anos eu era obrigado a ir buscar leite na comunidade de 37 [nome da comunidade] e depois ia para a escola. (...). Naquela época não existia telefone e o meio de transporte era o cavalo. Depois surgiu um ônibus velho movido a lenha. (...) Íamos aos bailes a pé, a uma distância de 8 km. Mais tarde foi comprado um caminhão e íamos em todo lugar com ele. Era uma felicidade só! (...)". Hoje ele é feliz e adora todos e eu me senti muito feliz por poder ser seu confidente nesta história. Texto escrito por G.L.M., aluno-autor, com base no depoimento de B. C., 75 anos.

O aluno/autor inicia o texto apresentando seu entrevistado/ narrador/ personagem, B.C. Em seguida, o aluno passa a palavra para B.C. (estratégia adequadamente reforçada pelo uso das aspas), que desenvolve então sua fala em primeira pessoa. Quase ao término do texto, as aspas são fechadas e o aluno reassume sua voz. Mesmo com alguns problemas na organização textual, o aluno faz uso de uma estratégia discursiva bastante plausível no âmbito do gênero memórias literárias, ou seja, demarca as vozes de quem fala no discurso e garante que as reminiscências propriamente ditas sejam relatadas em primeira pessoa. 0 estranhamento que fica para o leitor, no entanto, é que o autor não é parte integrante das memórias, nem mesmo como um personagem coadjuvante. Ele está ali mais como um espectador encarregado de registrar depoimentos, tal como acontece no texto do exemplo 1.

A caracterização do local feita por B.C, via contexto familiar ("éramos pobres"; "as famílias eram grandes"), práticas sociais mais frequentes (“íamos a igreja"; "era obrigado a ir buscar leite"; "ia para a escola”; "íamos aos bailes a pé") e serviços públicos disponíveis ou ausentes ("não existia telefone e o meio de transporte era o cavalo"; "ônibus movido a lenha"; "íamos em todo lugar com ele [caminhão]"), ajuda o leitor a construir uma imagem sobre o dia- 
a-dia na comunidade. Todavia, elementos ficcionais e próprios da linguagem literária, que poderiam tornar a narrativa mais vibrante e envolvente, e menos fragmentada e reificada, não se fazem presentes no texto. 0 término do texto basicamente reproduz a estratégia já comentada no exemplo 1. Há uma quebra na expectativa do leitor quanto ao gênero, ainda que (e isso é importante de ser ressaltado) a estratégia fique dentro dos limites postos pelos materiais pedagógicos da Olimpíada.

\section{EXEMPLO 3}

Como sempre quis saber como era antigamente, talvez por curiosidade - tive o privilégio de poder participar deste maravilhoso trabalho de pesquisa conhecimento e sabedoria entrevistando o meu avô, então em uma determinada data peguei uma caderneta e um lápis e me passei por jornalista perguntando ao meu avô A. A. R., de 67 anos e sua companheira A. S. O. de 63 anos, algumas perguntinhas da lista que fiz. Comecei questionando como era o nosso município, disseram que a cidade era muito simples, estrada de chão, poucas casas, uma igrejinha: Nossa Senhora Aparecida. Meu avô disse até que ele tinha estudado em uma escolinha (...). Perguntei se existia luz elétrica, segundo ele luz só tinha em casa da antiga firma: [nome da firma] e quem não tinha só usavam lampiões, a água utilizada era de poços artesianos, da bica ou compravam de carroceiros. Disseram que as moças só iam aos bailes acompanhadas com os pais (...). Então perguntei se os tempos de hoje são melhores do que antigamente. Responderam com a maior certeza, de que hoje é muito melhor do que antes (...). Quando parei de entrevistá-los fiquei muito feliz, pela sabedoria dos mais velhos e pela incrível evolução que o município de [nome da cidade] preserva.

A proposta dos materiais da Olimpíada de realizar um conjunto de atividades anteriores à produção das memórias literárias parece ter sido, em alguns casos, mal dimensionada e acabou se tornando, equivocadamente, parte integrante do relato dos alunos, como no caso do exemplo 3 ("sempre quis saber como era antigamente"; "pude participar deste maravilhoso trabalho de pesquisa”; "peguei uma caderneta e um lápis"; “me passei por jornalista”; "perguntinhas da lista que fiz"; "comecei questionando"; "quando parei de entrevistá-los"). Assim, apesar do aluno se reportar a algumas características do lugar ("cidade era muito simples"; "estrada de chão"; "poucas casas"; "uma igrejinha") e práticas sociais ("tinha estudado em uma escolinha"; "luz só da antiga firma”; “uso de lampiões”; “água de poços artesianos”, "bica ou carroceiros"; "moças iam aos bailes com os pais"), o texto se distancia acentuadamente do gênero memórias literárias. 0 aluno parece estar apenas relatando uma situação de entrevista e não consegue operar com as múltiplas vozes introduzidas no discurso. Mais precisamente, não disponibiliza a palavra para os entrevistados, mas assume ele próprio o papel de mediador das trocas de falas, demarcadas por verbos de elocução ou declarativos, 
como perguntar, dizer, questionar, acrescentar, contar. Por essa estratégia as reminiscências acabam sendo relatadas pelo viés do discurso indireto, quebrando a fluência, o ritmo do texto e a estrutura narrativa. Tal como no exemplo 2, o aluno também não recorre à literariedade e à ficcionalidade no desenrolar de seu texto, capacidade que, sem dúvida, se apresentou como um dos grandes desafios a ser enfrentado no ensino-aprendizagem do gênero memórias literárias.

\subsection{O TEMA O LUGAR ONDE VIVO E OS TEXTOS DOS ALUNOS}

No desenvolvimento do tema O lugar onde vivo (estabelecido, como já se indicou, pela Olimpíada para todos os gêneros), os aprendizes foram orientados, no caso da escrita das memórias literárias, a realizar entrevistas ${ }^{9}$ com antigos moradores e a buscar, junto aos entrevistados, informações particulares, interessantes, pitorescas, relevantes sobre a comunidade local em épocas passadas. Para tanto, no decorrer das entrevistas, deveriam empenhar-se em conseguir detalhamentos a respeito dos modos de viver do passado, das transformações físicas ocorridas no local, de profissões que deixaram de existir, de eventos marcantes, por exemplo.

Assim, no atendimento à temática, o momento da entrevista pode ser tido como o mais crucial do processo pois, por serem muito jovens, os estudantes não detêm lembranças diferenciadas sobre um passado mais remoto de sua localidade. A entrevista seria, nesse sentido, a ocasião mais propícia, senão única, para que o aluno recolhesse subsídios que, associados a eventos ficcionais, lhe permitissem ter o que dizer sobre a vida na localidade, nos tempos de outrora. Daí a relevância da escolha adequada da pessoa a ser entrevistada, que deveria não apenas conhecer histórias antigas do lugar mas também saber contá-las com vivacidade e envolvimento, de modo a motivar os aprendizes a reconstruí-las com um enfoque pessoal e do ponto de vista literário. Além disso, a própria preparação da entrevista precisaria receber um espaço considerável no encaminhamento pedagógico, pois perguntas que simplesmente "não rendem”, que não estimulam o entrevistado a falar, ou ainda perguntas desviantes (não direcionadas para o tema em questão), tendem a oferecer pouco material para registro. Na amostra de textos explorada, embora via de regra reminiscências sejam recuperadas, em grande parte elas ficam restritas à esfera privada do autor/narrador, sem que um elo mais consistente com o lugar seja estabelecido. Desse modo, acabam

De preferência, a entrevista deveria ser efetuada na escola, como indicado na p. 108 do "Se bem me lembro... Caderno do professor". 
retratando aspectos rotineiros, mas não singulares, situados num lugar genérico, sem identidade própria. Observemos os três exemplos a seguir:

\section{EXEMPLO 4}

Há muitas lembranças de meu tempo de criança que guardo em meu peito até hoje e levarei comigo a vida toda, mas nenhuma me emociona tanto quanto a de minha boneca de pano. (...). Durante toda minha infância, esses domingos deliciosos [de almoço com toda família] se repetiam, mas um deles sempre estará mais marcado no meu coração, porque nesse eu ganhei (...) a minha preciosa boneca Emília. (...). Hoje, já adulta e mãe (...) a bonequinha Emília ainda está guardada em meu quarto e quando eu a abraço sinto novamente o cheirinho e a energia de toda aquela feliz vivência (...). (Texto elaborado a partir da entrevista com M. C. C. C., 31 anos)

EXEMPLO 5

“(...) Sou o filho mais velho de oito irmãos e meus pais, J. M. A. e J. A. A., são nordestinos. (...) Nasci ali e cresci ajudando meu pai na lida das lavouras. Aos 15 anos, saí à procura de uma nova vida, pois ali não tínhamos opção de trabalho e eu queria muito crescer profissionalmente. Saí pelos caminhos do sertão nordestino só com algumas roupas na mala e dormindo pelas estradas". (...). Esta história é da vida do meu avô que viveu 83 anos já faz 10 anos que ele veio a falecer. (...). Saudades vovô J. M. A., quantas saudades. J. P. V. P., aluno-autor.

\section{EXEMPLO 6}

Viajando pelo tempo, voltando ao passado, navegando nas lembranças do Sr. J. pessoa humilde, batalhador, com uma história de vida incrivel. (...) Meados de 1929, quando tinha 8 anos, já era um garoto que ajudava o pai no campo, e ainda arranjava um tempinho para brincar de "boizinho" que era uma brincadeira onde ele pegava frutas como: manga, goiaba etc. enfiava gravetos simulando as pernas do boi e se sentia um grande fazendeiro, com sua fazenda "abarrotada de gado". (...). Lembro-me da minha primeira professora Dna D. e de sua palmatória que me castigava todas as vezes que me atrasei para ir a escola (...).Texto escrito com base no depoimento do Sr. J. B. S., conhecido como Sr J. de 89 anos.

Os exemplos 4, 5 e 6, associados aos exemplos 1, 2 e 3, são bastante representativos do que a amostra de textos nos proporciona em termos da abordagem temática. Assim, ora as produções trazem informações pontuais sobre características da localidade (textos 1 a 3), ora fogem ao tema proposto, por apresentarem reminiscências que não recuperam satisfatoriamente o contexto cultural e os valores do lugar onde vivem os narradores (textos $4 \mathrm{a}$ 6), muito em função das informações procurarem espelhar a realidade, sem qualquer movimento, tanto de aproximação do inventado quanto de investida na linguagem literária. 
No texto 4 o foco temático está voltado para os almoços de domingo e a boneca que a moradora ganhou em certa ocasião; no texto 5, o tema central é a história de vida do avô do autor, da infância à vida adulta, transcorrida em lugares diferentes; no texto 6, o aluno traz para o leitor algumas das brincadeiras de infância e experiências na escola do entrevistado. É possível que nos casos dos textos 4 a 6 , as entrevistas não tenham sido bem conduzidas, ou ainda que as pessoas não tenham sido adequadamente selecionadas, em termos do subsídio que poderiam oferecer para a escrita do aluno. No exemplo 4, a moradora tinha apenas 31 anos à época da entrevista, idade insuficiente para que ela pudesse maturar e relatar casos mais interessantes sobre a cidade, para além de suas vivências nos almoços em família e seu apego à boneca. No exemplo 5 não houve propriamente entrevista, pois, segundo o autor relata, as reminiscências são do avô, falecido há dez anos. No exemplo 60 aluno informa que o morador tem "uma história de vida incrível”, mas esta narrativa não se expande para a caracterização de peculiaridades da história cultural da comunidade na qual o entrevistado e o entrevistador estão inseridos.

\subsection{AS CONDIÇÕES DE TEXTUALIDADE E OS TEXTOS DOS ALUNOS}

No âmbito da textualidade, se considerados os materiais pedagógicos da Olimpíada, esperava-se que os alunos redigissem textos que atendessem à coesão, articulação e progressão, de forma a garantir a coerência esperada no gênero em tela e, por esse caminho, ajudassem seu leitor a construir a compreensão textual. Para tanto, seria importante que o autor estivesse atento, entre outros aspectos, ${ }^{10}$ ao manejo adequado da retomada dos referentes, ao emprego, quando necessário, de conectores, ao uso de tempos verbais e indicadores espaciais que recuperassem adequadamente as épocas e os lugares reportados nos textos. Outro aspecto a ser levado em conta seria a observância às convenções da escrita, tendo em vista que a situação comunicativa pressuposta - participação em um concurso de âmbito nacional - exigia uma cuidadosa releitura, revisão e, eventualmente, também uma reescrita dos textos. Os exemplos inseridos na sequência nos ajudam a compreender como os textos dos alunos se apresentam quanto aos fenômenos mencionados.

\section{EXEMPLO 7}

Nasci em [nome do município] em um período que as coisas eram muito diferentes de hoje, naquela época namorar era um assunto muito sério (...). Outro assunto da minha época era 10 Outros fenômenos, além dos aqui citados, compõem a textualização. Preferimos, no entanto, nos ater aos indicados, por serem os mais salientes nos textos dos alunos. 
a vida difícil, muitas pessoas morriam de doenças que ninguém conhecia ou de fome, nós tínhamos de trabalhar na roça (...). Em 1958 houve a maior seca já vista nesta região nem sei como nós sobrevivemos, porque as roças não deram sequer um pé de arroz ou de feijão. (...). Eu lembro das danças daquela época como a dança de São Gonçalo, a família toda gostava de participar, íamos de jumento, os pequenos iam no grajau ${ }^{11}$ e os maiores iam no meio da cangalha e nós íamos a pé, outra coisa diferente era o jeito das roupas, eu gostava de comprar algodão para fazer redes e algumas peças de roupas.

Para que um texto do gênero memórias literárias ${ }^{12}$ progrida, é importante que as informações novas sejam de algum modo ancoradas em referentes anteriores, de forma que o leitor não perca o fio da meada. Este cuidado não se fez presente de modo satisfatório nos textos estudados na amostra. Com relativa frequência os autores elaboraram grandes listagens das reminiscências que lhes foram contadas, sem a preocupação de organizá-las numa narrativa coerente e articulada.

No exemplo 7 o narrador informa seu local de nascimento e, em seguida, indica como aconteciam os namoros. Posteriormente, sem estabelecer qualquer vínculo com o assunto 'namoro', explicita a dificuldade causada, na época (não situada), pelas mortes provocadas por doenças desconhecidas ou mesmo pela fome. 0 texto prossegue, introduzindo ocorrências que guardam pouca relação entre si. Do ponto de vista temporal, a única referência disponível é o ano de 1958, quando, segundo informa o texto, "houve a maior seca já vista na região". Todavia, na sequência, o narrador diz lembrar-se “das danças daquela época”, das quais “a família toda gostava de participar”. A qual época refere-se o narrador? Provavelmente não à mesma em que ocorreu a grande seca, mas isso não é esclarecido. E mais, os fatos relatados foram vivenciados quando o narrador era criança, jovem ou adulto? Esta é uma questão que o leitor não consegue resolver, sobretudo quando se considera o trecho: "íamos de jumento, os pequenos iam no grajau e os maiores iam no meio da cangalha e nós íamos a pé" (ênfases acrescidas).

\section{EXEMPLO 8}

(...) quando lembro do tempo em que era jovem recordo de muitas coisas diferentes. $O$ jeito de namorar era uma delas, eu de um lado minha mãe do outro e meu namorado perto de mim. Gostava de frequentar a escola, minha professora era muito brava. (...). Minha mãe costurava, fazia balaios (...) ela também preparava as refeições, elas eram feitas num fogão a

O significado do termo não é explicado no texto do aluno.

12 A progressão pode ocorrer de forma diferenciada, tendo em vista o gênero textual, o espaço social em que o texto irá circular, o leitor presumido, o conhecimento de mundo partilhado etc. 
lenha. Eu usava vestidos longos abaixo do joelho. Comprava tecidos para fazer os vestidos, os tecidos e outras coisas era comprado nos armazéns. $O$ relacionamento com meus pais havia muito respeito com eles, com os idosos e também com as demais pessoas. Aos domingos eu sempre reunia com meus vizinhos ou parentes para almoçar-mos juntas. (...). A maioria das pessoas morava na zona rural assim como minh a família em pequenas casas. A escola que eu estudava era muito simples. Eu e meus colegas sentávamos em bancos e em dupla. O hospital da cidade tinha poucos recursos. (...).

No texto 8 a autora introduz vários referentes sem articulá-los entre si. Com isso, vai deixando lacunas que dificultam a construção da progressão textual. Observa-se que do assunto "jeito de namorar" o narrador passa para o prazer de "frequentar a escola" e, de forma aparentemente contraditória, justifica este prazer pelo fato da "professora ser muito brava". Na sequência do texto, depois de apontar as atividades desenvolvidas pela mãe ("costurava, fazia balaios, preparava as refeições"), a jovem se reporta aos "vestidos longos abaixo do joelho" que usava. Em seguida o foco temático passa do relacionamento respeitoso com os pais e idosos para as reuniões de domingo, e deste para a constatação de que as pessoas moravam, em sua maioria, na zona rural. Evidenciando mais uma vez a quebra na progressão temática, a aluna retoma o tópico "escola” e, sem qualquer tipo de transição discursiva, declara que "o hospital da cidade tinha poucos recursos". Podese supor que a aluna foi exposta a um grande arsenal de informações sobre a biografia do entrevistado, mas não conseguiu dar uma unidade à narrativa (ou não foi devidamente orientada para isso), tangenciando a articulação temática. Outro fator que contribui para a dificuldade do leitor em integrar as passagens soltas ao todo é a ausência de uma preocupação da aluna-autora com a contextualização temporal.

\section{EXEMPLO 9}

Eu, meus três irmãos, minha irmã e meus pais, vivíamos uma vida simples, (...) eu e meus colegas adorávamos brincar de pular corda, pega-pega. (...). Na escola, eu e minha irmã nem tinhamos muita roupa para vestir, então vestíamos as roupas iguais e o povo da escola ria muito, mas nada disso nos importava, pois nossa família vivia unida e adorávamos ir ao sítio da minha avó afinal, o ar de lá é muito puro, bebíamos leite de vaca, subíamos nos pés de frutas e havia muita plantação de roça. O momento mais marcante foi na minha formatura, onde todos nós, da nossa classe e os meus professores fizemos uma viagem de navio e tivemos um almoço muito especial. Esse dia foi inesquecível... Houve também um dia, na sala de aula, que uma professora chegou a quase me bater com a régua, só porque eu desenhei no caderno afinal, naquela época o ensino era muito rigoroso. O namoro na minha juventude era muito respeitoso, agora hoje em dia muitas coisas mudaram... (...).

Como nos exemplos anteriores, um aspecto que chama a atenção no texto 9 
é a forma pouco articulada com que a aluna-autora organiza as informações. Algumas delas, inclusive, parecem não guardar qualquer relação com a anterior nem com a subsequente. Assim, após um relato a respeito da "vida simples e das brincadeiras da infância", a aluna-autora declara que "ela e a irmã não tinham muitas roupas para vestir, mas isso não importava, pois a família era unida e adorava ir ao sítio da avó beber leite e subir nos pés de frutas". Do sítio da avó a jovem passa para o momento da formatura, descrito como "inesquecível", para, em seguida, retornar a um fato transcorrido em sala de aula, provavelmente antes da formatura, sem que, ao longo deste percurso, seja providenciada a devida contextualização. No processo de produção parece que o aprendiz elimina as perguntas preparadas para a entrevista e compõe seu texto apenas justapondo as respostas, sem atentar para a importância de articuladores adequados ao gênero. Em função destas quebras as ideias ficam soltas e a tessitura textual sofre prejuízos.

No que se refere aos aspectos mais gerais da textualidade, relacionados às convenções da modalidade escrita da língua, os textos 7, 8 e 9 apresentam problemas notadamente quanto às regras de pontuação e de morfossintaxe, como a concordância e a regência adequada dos verbos. São problemas que comprometem a coerência textual e mereceriam ser melhor trabalhados no âmbito das orientações pedagógicas para a elaboração textual.

\section{PARA CONCLUIR}

Embora o contato com histórias de vida seja bastante frequente na faixa etária em que se encontram os alunos do sétimo e do oitavo ano do Ensino Fundamental, a familiaridade dos aprendizes com o gênero memórias literárias e a transposição das narrativas vivenciadas por terceiros para a autoria em primeira pessoa é restrita. Considere-se ainda que, nas práticas sociais, as memórias literárias aparecem associadas a gêneros de maior fôlego, como romances, ainda que sejam perceptíveis em outros, como poemas e contos, e a autores mais experientes e maduros. No contexto pedagógico da Olimpíada, todavia, as memórias estão vinculadas, sobretudo, a narrativas curtas, na escrita, e a fragmentos de romance, na leitura, bem como a um tema que deve ser alimentado por entrevistas nem sempre pródigas em subsídios para o desenvolvimento satisfatório da tarefa. Assim, a tensão provocada por um certo distanciamento entre as práticas sociais extraescolares e as práticas de sala de aula poderia, pelo menos em parte, explicar a relativa dificuldade encontrada pelos alunos no desenvolvimento do gênero memórias literárias, tal como solicitado nas condições de produção. 
Por outro lado é importante lembrar que, para muitos aprendizes, o trabalho nas oficinas representou provavelmente o primeiro contato sistematizado com a elaborada estratégia discursiva de lidar com as múltiplas vozes do discurso; a primeira oportunidade de ampliar, de modo consequente, sua bagagem de leitura literária; e uma das poucas chances de tanto desenvolver competências de escrita para interagir com leitores virtuais, quanto de se expor à crítica na posição de autor, para além da sala de aula.

Assim, na superação das questões identificadas, parece ser bastante promissor um trabalho que leve o aluno a se colocar no papel de um leitor crítico do seu próprio texto e do seu colega, sem perder de vista as práticas sociais em que o gênero trabalhado circula. Ressalte-se ainda que a capacidade para a produção de textos dos jovens autores não será construída com a realização de uma única sequência didática visando à aprendizagem de um único gênero. Por isso mesmo, a participação na Olimpíada precisaria ser vista por alunos e professores como uma importante oportunidade a mais, mas certamente não exclusiva, de trabalho com a escrita. A Olimpíada oportuniza, pois, um momento rico de formação, que pode ser transposto para a prática pedagógica de escrita de outros gêneros textuais e de outros temas. 


\section{Writing in the literary memoir genre in the academic space: challenges and possibilities}

\section{ABSTRACT}

This study takes a socio-discursive conception of language and develops reflections on the challenges and possibilities present in the process of writing literary memoirs in educational practice. To do this, the notions of written production, text genres and the educational process are initially explored. Next, a more detailed discussion takes place on the genre of literary memoirs. Following this, considering the conditions for production provided by the Portuguese Language Olympics - Writing the Future, in 2010, an analysis is done of literary memoir texts produced by students taking part in the contest. The results of the investigation point to satisfactory performance from the learners in meeting the general conditions of production, while at the same time that they locate the main hardships faced by students in managing a discursive standpoint and in the use of literary language.

\section{KEYWORDS}

Literary memoirs. Written production. Academic space. Text genres. 


\section{Referências}

AGUIAR, Joaquim Alves de. Espaços da memória: um estudo sobre Pedro Nava. São Paulo: Edusp; Fapesp, 1998.

CENPEC. Se bem me lembro. Caderno do professor: orientações para produção de textos. Equipe de produção: Regina Andrade Clara, Anna Helena Altenfelder e Neide Almeida. São Paulo: Cenpec, 2010. Coleção da Olimpíada.

BAZERMAN, Charles. Gêneros textuais, tipificação e interação. Organização de Angela Paiva Dionísio e Judith Chambliss Hoffnagel. São Paulo: Cortez, 2005.

CAVALLO, Guglielmo. Entre volume e codex: a leitura no mundo romano. In: CAVALLO, Guglielmo e CHARTIER, Roger (Org.). História da leitura no mundo ocidental: v. 1. São Paulo: Ática, 1998. p. 71-102.

CORRÊA, Hércules. A formação do leitor em livros de memórias: leituras em Infância, de Graciliano Ramos, e 0 menino da mata e seu cão Piloto, de Vivaldi Moreira. In: PAIVA, Aparecida. et al. (Org.). Literatura: saberes em movimento. Belo Horizonte: Ceale; Autêntica, 2007, p. 155-169.

DOLZ, Joaquim; GAGNON, Roxane; DECÂNDIO, Fabrício. Produção escrita e dificuldades de aprendizagem. Campinas/SP: Mercado de Letras, 2010.

JAGUARIBE, Vicência Maria Freitas. Os caprichos e as condescendências do discurso literário. In: CAVALCANTE, Mônica Magalhães. et al. (Org.). Texto e discurso sob múltiplos olhares: referenciação e outros domínios discursivos: v. 2. São Paulo: Lucerna, 2007. p. 221-249.

LIMA, Gercina Ângela Borém. A transmissão do conhecimento através do tempo: da tradição oral ao hipertexto. Revista Interamericana de Bibliotecología, Medelín (Colômbia), v. 30, n. 2, p. 275-285, Jul./Dez. 2007. Disponível em: 〈http://aprendeenlinea.udea.edu.co/revistas/index.php/ RIB/article/viewFile/1881/1553〉Acesso em: 07/05/2012.

MAINGUENEAU, Dominique. Discurso literário. São Paulo: Contexto, 2009.

MARCUSCHI, Beth. Escrevendo na escola para a vida. In: RANGEL, Egon de Oliveira e ROJO, Roxane (Coord.). Língua Portuguesa: Coleção Explorando o Ensino: v. 19. Brasília: Ministério da Educação, Secretaria de Educação Básica, 2010. p. 65-84.

MARCUSCHI, Luiz Antônio. A linguagem no cotidiano e na literatura: como 
enquadrar o ensino de ambos com base nos gêneros textuais? In: CONGRESSO DE LEITURA (COLE), 15, 2005. [Comunicação...] Campinas: [s.n.], 2005. 18 p. inédito.

MARCUSCHI, Luiz Antonio. Produção textual, análise de gêneros e compreensão. São Paulo: Parábola, 2008.

MILLER, Carolyn. Estudos sobre gênero textual, agência e tecnologia. Organização de Angela Paiva Dionísio e Judith Chambliss Hoffnagel. Recife: Editora Universitária da UFPE, 2009.

NAVA, Pedro. Balão Cativo. Rio de Janeiro: José Olympio, 1977.

PAULINO, Maria das Graças Rodrigues. Algumas especificidades da leitura literária. In: PAIVA, Aparecida. et al. (Org). Leituras literárias: discursos transitivos. Belo Horizonte: Ceale; Autêntica, 2005. p. 55-68.

SARAMAGO, José. As pequenas memórias. São Paulo: Companhia das Letras, 2006.

SCHNEUWLY, Bernard; DOLZ, Joaquim. Os gêneros escolares: das práticas de linguagem aos objetos de ensino. In: SCHNEUWLY, Bernard; DOLZ, Joaquim. Gêneros orais e escritos na escola. Campinas/SP: Mercado de Letras, 2004. p. 71-91.

Recebido em: MAIO de 2012

Aprovado em: JUNHO de 2012 